thrombolysis the treatment may cause intramyocardial haemorrhage, which may predispose to cardiac rupture. ${ }^{19}$

Furthermore, though thrombolytic treatment has been shown to reduce the size of the infarct and mortality, improvements in left ventricular function have been less striking. The reasons for this discrepancy have been a source of debate, and the traditionally accepted relation between patency of the coronary artery, myocardial salvage, and ventricular function has been questioned. Restoration of the patency of vessels may not in itself be sufficient to restore myocardial contractile function in all patients. These findings imply that there is a trade off between the early problems of thrombolytic treatment and the longer term benefits. They may also represent a previously hidden manifestation of reperfusion injury.

The clinical evidence strongly suggests that the components of reperfusion injury identified in the laboratory are of practical importance. Myocardial reperfusion may not benefit all patients and may actually be harmful to some. Components of reperfusion injury may occur not only in isolation but also in combination-when more profound consequences might be expected. The exact mechanisms of reperfusion injury are uncertain, but they probably include cellular overload of calcium, osmotic cell swelling, and myocyte or microvascular damage from cytotoxic free radicals derived from oxygen. The evidence for this last mechanism comes from interventional studies designed to show whether agents targeting

1 Tennant R, Wiggers CJ. The effect of coronary occlusion on myocardial interaction. Am f Physiol 1935;12:351-61.

2 Manning AS, Hearse DJ. Reperfusion-induced arrhythmia: mechanisms and prevention. $f \mathrm{Mol}$ Cell Cardiol 1984;16:497-518.

3 Goldberg S, Greenspon AJ, Urban PL, Muza B, Berger B, Walinsky P, et al. Reperfusion arrhythmia: a marker of restoration of antegrade flow during intracoronary thrombolysis for acute myocardial infarction. Am Heart $\mathcal{f}$ 1983;105:26-32.

4 Grines CL, Browne KF, Marco J, Rothbaum D, Stone GW, O'Keefe J, et al. A comparison of immediate angioplasty with thrombolytic therapy for acute myocardial infarction. $N$ Engl $\mathcal{F}$ Med 1993;328:673-9.

5 Grech ED, Ramsdale DR. Termination of reperfusion arthythmias by coronary artery occlusion Br Hearr f 1994;72:94-5.

6 ISIS-2 Collaborative Group. Randomised trial of intravenous streptokinase, oral aspirin, both or neither among 17187 cases of suspected acute myocardial infarction: ISIS-2. Lancet 1988;ii: neither

7 Lie JT. Cardic

J Cardiovascular controversies. The reasons why clinical cardiologists disregard reperfusion arrhythmias. Cardiovascular Res 1993;27:1906.

8 Yamazaki S, Fujibayashi Y, Rajagopalan RE, Meerbaum S, Corday E. Effects of staged versus sudden reperfusion after acute coronary occlusion in the dog. $₹$ Am Coll Cardiol 1986;7:564-72.

9 Gruppo Italiano per lo Studio della Streptochinasi nell'Infarto Miocardico (GISSI). Effectiveness of intravenous thrombolytic treatment in acute myocardial infarction. Lancet 1986;i:397-402.

10 ISIS-3 (Third International Study of Infarct Survival) Collaboratiave Group. ISIS-3: a randomised comparison of streptokinase vs tissue plasminogen activator vs anistreplase and of aspirin plus heparin vs aspirin alone among $\mathbf{4 1} 299$ cases of suspected acute myocardial infarction. Lancet 1992;339:753-70.

11 Balke CW, Kaplinski E, Michelson EL, Naito M, Dreifus LS. Reperfusion ventricular the formation of free radicals might protect against reperfusion injury. ${ }^{20}$ Direct evidence of the presence of free radicals has now been provided by electron paramagnetic resonance spectroscopy and spin trapping techniques in coronary venous effluent blood, before and after primary angioplasty reperfusion. ${ }^{21}$ Nevertheless, confirming the presence of free radicals does not in itself indicate that reperfusion injury has occurred or that free radicals are the only mediators of reperfusion injury. Further clinical studies are needed to examine closely the relation between free radical generation and various components of myocardial reperfusion injury. Only when these data are available can the potential benefits of adjuvant pharmacological agents in modulating the extent of tissue injury be determined by randomised clinical trials.

EVER D GRECH Senior registrar in cardiology

Royal Brompton National Heart and Lung Hospital,

London SW3 6NP

Department of Medicine,

Royal Liverpool University Hospital,

Liverpool L69 3BX

MALCOLM J JACKSON Professor of cellular pathophysiology

Department of Cardiology,

Cardiothoracic Centre,

Liverpool L14 3PE

tachyarrhythmias: correlation with antecedent coronary artery occlusion tachyarrhythmias and duration of myocardial ischemia. Am Heart $f$ 1981;101:449-56.

12 European Myocardial Infarction Project Group. Prehospital thrombolytic therapy in patients with suspected acute myocardial infarction. N Engl f Med 1993;329:383-9.

13 Ellis SG, Henschke CI, Sandor T, Wynne J, Braunwald E, Kloner RA. Time course of functional and biochemical recovery of myocardium salvaged by reperfusion. $\mathrm{Am} f$ Coll Cardio 1983;1:1047-55.

14 Schmidt WG, Sheehan FH, von Essen R, Vebis R, Effert S. Evolution of left ventricular function after intracoronary thrombolysis for acute myocardial infarction. Am $\mathcal{f}$ Cardiol 1989;63: 497-502.

15 Bolli R, Hartley CJ, Rabinovitz RS. Clinical relevance of "myocardial stunning." Cardiovasc Drugs Ther 1991;5:877-90.

16 Kloner RA. Does reperfusion injury exist in humans? $\mathcal{F}$ Am Coll Cardiol 1993;21:537-45.

17 Ellis SE; Wynne J, Braunwald E, Henschke CI, Sandor T, Kloner RA. Response of reperfusions SE; Wynne J, Braunwald E, Henschke CI, Sandor T, Kloner RA. Response of
salvaged, stunned myocardium to inotropic-stimulation. Am Heart $\mathcal{f}$ 1984;107:9-13.

salvaged, stunned myocardium to inotropic-stimulation. Am Heart $f$ 1984;107:9-13.
18 Hearse DJ. Reperfusion of the ischemic myocardium. $₹$ Mol Cell Cardiol 1977;9:605-16.

19 Waller BF, Rothbaum DA, Pinkerton CA, Cowley MJ, Linnemeier TJ, Orr C, et al. Status of the maller BF, Rothbaum DA, Pinkerton CA, Cowley MJ, Linnemeier TJ, Orr C, et al. Status of the
myocardium and infarct-related coronary artery in 19 necropsy patients with acute recanalization using pharmacologic (streptokinase, r-tissue plasminogen activator), mechanical (percutaneous transluminal coronary angioplasty), or combined types of reperfusion therapy. $₹$ Am Coll Cardio 1987;9:785-801.

20 Bolli R. Oxygen-derived free radicals and myocardial reperfusion injury: an overview. Cardiovasc Drugs Ther 1991;5(suppl 2):249-68.

21 Grech ED, Dodd NJF, Bellamy CM, Faragher EB, Morrison WL, Ramsdale DR. Detection of circulating free radicals following angioplasty reperfusion for acute myocardial infarction. Circulation 1993;88:I-157.

\title{
Racial discrimination in medicine
}

\section{Equity for patients is unlikely if we don't treat doctors fairly}

There is now considerable evidence that people from minority ethnic groups are discriminated against at each stage of their medical careers. ${ }^{1-9}$ This week's $B M \mathcal{F}$ carries two papers that point to continuing discrimination on application to medical school. ${ }^{2}$ McManus et al studied nearly 7000 students who applied to one of five chosen medical schools in 1991 and showed that similarly qualified applicants from minority ethnic groups were 1.46 times more likely to be rejected than their white peers (p 496). ${ }^{1}$ Esmail et al found a similar pattern among all applicants to medical school in 1992 (p 501). ${ }^{2}$ These papers add to the picture painted by the original reports by McManus's group on medical school applicants in 1981 and $1986^{34}$ and to the report of the Commission for Racial
Equality which showed discriminatory practices in the admissions procedure at St George's Hospital Medical School, London. ${ }^{6}$

Once admitted to medical school the problems do not stop. A recent report revealed that Asian students at Manchester University Medical School (mostly UK born) were more likely than white students to fail final clinical examinations despite good performance in their written exams. ${ }^{6}$

Once qualified the discrimination continues. Two surveys from the late 1980s concluded that, as a group, doctors from minority ethnic groups had more unsuccessful applications for jobs, were less likely to be able to pursue their chosen career, and were more likely to experience long periods 
of unemployment when trying to obtain a registrar post. ${ }^{78}$

That these difficulties are due, at least in part, to discrimination was shown by Esmail and Everington in 1993.9 They sent matched pairs of curriculum vitae-one bearing an English name and one an Asian name-in response to 23 advertisements for senior house officer posts. The applicants with English names were more likely to be shortlisted.

In the late 1980s and early 1990s there was a flurry of initiatives to combat discrimination in medicine. In 1989 the Universities Central Council on Admissions started monitoring the ethnic status of applicants. A joint task force was also set up by the Department of Health and the King Edward's Hospital Fund for London to report on how to achieve racial equality in selecting hospital doctors. It produced guidance for all those involved in selection procedures in $1990 .^{10}$ The NHS Executive issued specific guidelines on equal opportunities in recruitment and selection procedures in 1991." ${ }^{11}$. But the papers published in this week's $B M \mathcal{~ , ~ t h e ~ r e c e n t ~ r e p o r t ~ f r o m ~ M a n c h e s t e r , ~ a n d ~ t h e ~ f a c t ~}$ that Esmail and Everington were still able to show overt discrimination in 1993 indicate that these measures were not enough. This is partly because the guidelines are voluntary but also because they have not been linked to any effective monitoring of their impact.

If we wish to eradicate a systematic problem we need a systematic approach. The Commission for Racial Equality has produced guidance to help employers to be more rigorous in their attempts at achieving racial equality. Their booklet, Racial Equality Means Business: A Standard for Racial Equality for Employers gives a step by step guide on how to develop strategies and monitoring schemes. It also goes further by showing how to monitor the impact of these strategies in areas of policy and planning; selecting, developing, and retaining staff; communicating the corporate image, corporate citizenship, and auditing for racial equality. ${ }^{12}$ There is a strong case for the commission's standard to be made mandatory across the whole NHS and in every medical school. This should be centrally coordinated so data across the NHS could be made available. It could produce information on applications, shortlisting, and success rates at interview for all groups who are discriminated against and tie these to a process of audit and development. It could identify where change is necessary nationally and locally.

Audit can yield dividends. McManus et al have used the ethnic monitoring data from university admission forms to identify areas where change could make medical school selection fairer. Similarly, the working party set up after the examination failures in Manchester has called for more structured marking in clinical examinations to cut down the opportunities for discrimination. ${ }^{6}$

The discrimination which is evident in medicine means that good students are denied places at medical school and good doctors denied their chosen careers. If we do not choose the best person for the job because of his or her ethnic background then the practice of medicine suffers from the wasted potential as much as the individual. The image of medicine in the eyes of patients is also damaged. From April this year the NHS is to undertake mandatory ethnic monitoring of all patients to increase equity of care, but we are unlikely to produce an equitable NHS for patients if we do not have the will to produce it for doctors.

$B M 7$,

KWAME J MCKENZIE Visiting associate editor

London WC1H

1 McManus IC Richards P, Winder BC, Proston KA, Styles V. Medical school applicants from minority ethnic groups: identifying if and when they are disadvantaged. $B M 71995 ; 310: 496-500$.

2 Esmail A, Nelson P, Primarolo D, Toma T. Acceptance into medical school and racial discrimination. $B M \mathcal{F}$ 1995;310:501-2.

3 McManus IC, Richards P. Audit of admissions to medical school. 1. Acceptances and rejects. BMF 1984;289:1201-4.

4 McManus IC, Richards P, Maitlis SL. Prospective study of the disadvantage of people from ethnic minority groups applying to medical school in the United Kingdom. BMF 1989;298:723-6.

5 Commission for Racial Equality. Report of a formal investigation into St George's Hospital Medical School. London: CRE, 1988.

6 Dillner L. Manchester tackles failure rate of Asian students. $B M F$ 1995;310:209.

7 Commission for Racial Equality. Overseas Doctors: A Research Study. London: CRE, 1987.

8 McKeigue PM, Richards JDM, Richards P. Effects of discrimination by sex and race on the early areers of British medical graduates during 1981-7. BMF 1990;301:961-4.

9 Essmail A, Everington S. Racial discrimination against doctors from ethnic minorities. $B M \mathfrak{I}$ 1993;306:691-2.

\section{Analgesic headache}

\section{A common, treatable condition that deserves more attention}

"Do no harm" is the first commandment for clinicians, but effective drug treatment cannot be given without exposing patients to the risk of side effects. One side effect quite often observed in the treatment of headache is rarely seen in other conditions: the treatment may aggravate the symptom for which it has been given. Ergotamine, narcotics, and even mild analgesics may all aggravate tension headache and migraine when taken daily. ${ }^{2}$

Ergotamine has a relatively short half life in plasma but a longlasting effect on arteries, ${ }^{3}$ and its frequent use may induce almost permanent vasoconstriction. ${ }^{4}$ Headache induced by ergotamine is of two types. ${ }^{5}$ One type is associated with daily use of ergotamine and is present almost constantly but fluctuates in intensity and characteristics: sometimes it fulfils the criteria for migraine, but at other times it does not. The second type is associated with sudden discontinuation of daily ergotamine, and this may cause a severe and protracted attack of migraine. Vasodilatory counteracting mechanisms that develop during chronic use of ergotamine are left unopposed when the drug is withdrawn, and this may explain the ergotamine withdrawal headache. The only effective treatment is to start ergotamine again, so the patient is caught in a vicious circle of use and abstinence from the drug. Admission to hospital may be needed to break this pattern.

Sumatriptan, the specific remedy against migraine that was introduced recently, may theoretically cause the same problems. Treatment with sumatriptan has been shown to ameliorate ergotamine withdrawal headache. ${ }^{6}$ In most migraine centres a few patients have been found to be misusing sumatriptan, ${ }^{7}$ but the drug seems only rarely to aggravate headache or migraine in people who are not already misusing another drug. The pharmacological differences between ergotamine and sumatriptan probably explain why sumatriptan rarely causes drug induced headache and why stopping overconsumption is relatively easy.

In Denmark narcotics have been widely used for migraine. As a result, each year, an estimated 13 people per million have become dependent on these drugs after taking them for migraine. ${ }^{8}$ Recently the problem has been brought under control by education of the profession. Centrally acting 